\title{
Sound Sampling, a Permitted Use Under EU Copyright Law? Opinion of the European Copyright Society in Relation to the Pending Reference before the CJEU in Case C-476/17, Pelham GmbH v. Hütter
}

\author{
Lionel Bently $\cdot$ Séverine Dusollier $\cdot$ Christophe Geiger $\cdot$ Jonathan Griffiths \\ Axel Metzger • Alexander Peukert • Martin Senftleben
}

Published online: 14 March 2019

(C) The Author(s) 2019

\begin{abstract}
This Opinion from the European Copyright Society (ECS) discusses the legal boundaries of the use of sound sampling under copyright law in the context of the currently pending CJEU case 476/17 (Pelham GmbH v. Hütter). The ECS recommends a careful interpretation of the scope of the phonogram producer's right. In the absence of any threshold or condition for protection, this right will extend to cover minimal parts of phonograms and will exceed the protection offered to works in
\end{abstract}

\section{Bently}

Professor at the University of Cambridge, Cambridge, UK

e-mail: 1b329@cam.ac.uk

\section{S. Dusollier}

Professor, School of Law, SciencesPo, Paris, France

e-mail: severine.dusollier@sciencespo.fr

\section{Geiger}

Professor of Law, Director General and Director of the Research Department at Centre d'Etudes Internationales de la Propriété Intellectuelle (CEIPI), University of Strasbourg, Strasbourg, France e-mail: christophe.geiger@ceipi.edu

\section{J. Griffiths $(\bowtie)$}

Professor of Intellectual Property Law at the School of Law, Queen Mary University of London, London, UK

e-mail: j.griffiths@qmul.ac.uk

\section{A. Metzger}

Professor of Civil and Intellectual Property Law at the Humboldt-Universität, Berlin, Germany

\author{
A. Peukert \\ Professor of Law at the Goethe-Universität Frankfurt am Main, Frankfurt, Germany \\ e-mail: a.peukert@jur.uni-frankfurt.de
}

\section{Senftleben}

Professor of Intellectual Property at the VU University Amsterdam, Amsterdam, Netherlands e-mail: m.r.f.senftleben@vu.nl 
copyright law. Sampling should only be covered by the phonogram producer's rights where it significantly prejudices the economic interests of the right holder. The ECS also argues that the quotation exception in Art. 5(3)(d) InfoSoc Directive should apply to sound sampling, even where it is not evident to the listener that another person's work or subject matter is being used in the form of a sound sample. However, such use requires that the source, including the author's name, should be given in the description of the work. In this regard, the ECS reiterates the duty of the CJEU to interpret the provisions of EU Directives in a manner that ensures compatibility with the Charter of Fundamental Rights of the European Union, especially the freedom of the arts (Art. 13) and the freedom of expression and information (Art. 11). In the introduction below, Advocate General Szpunar's Opinion (which takes a very different view on the issues referred by the national court) is also briefly considered.

Keywords European Copyright Society (ECS) - Sound sampling · Quotation exception · Pelham GmbH v. Hütter

\section{Introduction}

The following sets out the Opinion of the European Copyright Society (ECS) on (C476/17) Pelham GmbH v. Hütter, which is currently pending before the CJEU. The ECS argues in favour of a careful interpretation of the scope of the phonogram producer's right, suggesting that sampling should only be covered by the right where it significantly prejudices the economic interests of the right holder. The ECS also proposes that the quotation exception in Art. 5(3)(d) of the Information Society Directive might apply to sound sampling even where it is not evident to a listener that another person's work or subject matter is being used in the form of a sound sample. Furthermore, the ECS reiterates the duty of the CJEU to interpret the provisions of EU Directives in a manner that ensures compatibility with the Charter of Fundamental Rights of the European Union, especially the freedom of the arts (Art. 13) and the freedom of expression and information (Art. 11).

Advocate General Szpunar has now delivered his Opinion in Pelham GmbH. He takes a very different view of the answers which should be provided to the referring court. ${ }^{1}$ He considers inter alia that the taking of an extract from a sound recording for the purpose of sampling will infringe the reproduction right (even where the sampling is of a de minimis extract), that the "free use" provision in German copyright law is incompatible with Union law in so far as it exceeds the scope of the exceptions and limitations set out in Art. 5 of the Information Society Directive and that the quotation exception provided for in Art. 5(3)(d) of that Directive does not apply where (i) an extract from a sound recording has been incorporated into another recording without any interaction between extract and first recording or (ii) the extract forms an indistinguishable part of the second recording. He further advises the Court that the exclusive right of sound recording producers to control

\footnotetext{
${ }^{1}$ Case C-476/17 Pelham GmbH v. Hütter, Opinion of Advocate General Szpunar, 12 December 2018 EU:C:2018:1002.
} 
sampling does not contravene the freedom of arts as enshrined in Art. 13 of the Charter of Fundamental Rights.

In this introduction, we do not intend to discuss the Advocate General's Opinion in detail. Readers of the two documents will rapidly appreciate that it takes a very different view of the principles which ought to apply in a case such as this. Nevertheless, a number of legal inconsistencies and policy risks seem likely to arise if the Court were to follow the advice of its Advocate General in this case. The most important of these are:

a) By granting protection to two seconds of the phonogram, which is a minimal part of the whole, the CJEU offers an unlimited form of protection that is excessive by comparison with that which is available under copyright law. Whereas copyright would be limited to original parts of works, leaving mere notes, sounds and words unprotected, ${ }^{2}$ the neighbouring right of the phonogram producer, as interpreted by the Advocate General, would extend to such elements without precondition of any kind. This would create a monstrous IP right, unlimited in its subject matter. The Advocate General considers that the phonogram is protected "on account of the fixation itself" and not on account of an investment or of an arrangement of sounds. If that were correct, a mere act of technical fixation would be granted better protection than creativity. The objective of the related right of phonogram producers, namely to protect and reward the investment made in the sound recording, dictates that the protection granted to such producers should be limited to circumstances in which a substantial part of the investment has been copied or when the copying prejudices the investment.

b) In considering the application of the Charter's fundamental rights in Union copyright law, the Advocate General's Opinion takes an approach that is difficult to reconcile with that adopted by the Grand Chamber of the Court in (C-201/13) Deckmyn v. Vandersteen. ${ }^{3}$ Advocate General Szpunar accords a broad margin of discretion to the legislature and states that, save in exceptional circumstances, ${ }^{4}$ any supervisory control of the court must be undertaken within

\footnotetext{
${ }^{2}$ Case C-5/08, Infopaq, 16 July 2009, EU:C:2009:465; para. 45. See also Case 406/10, SAS Institute, 2 May 2012, EU:C:2012:259, para. 66.

${ }^{3}$ Case C-201/13 Johan Deckmyn Vrijheidsfonds VZW v. Helena Vandersteen, 3 September 2014, EU:C:2014: 2132.

${ }^{4}$ Advocate General Szpunar thus reiterates the position previously expressed in his Opinion on Case C-469/17, Funke Medien NRW GmbH v. Federal Republic of Germany, delivered on 25 October 2018 (EU:C:2018:870), stating that "there may be exceptional cases where copyright, which, in other circumstances, could quite legitimately enjoy legal and judicial protection, must yield to an overriding interest relating to the implementation of a fundamental right or freedom" (emphasis added, para. 38 of the Opinion). He thus seems to consider that copyright can be limited beyond the internal balances by freedom of expression in exceptional circumstances (see Geiger and Izyumenko (2019) (forthcoming). However, it is not entirely clear when such an "exceptional" situation might arise. In his most recent Opinion in Case C-516/17, Spiegel Online GmbH v. Volker Beck, 10 January 2019, the AG seems to take an even more restrictive approach, stating that an exceptional circumstance allowing the judge to step in beyond the legislative balances can only be admitted when the "essential core of a fundamental right is violated" (para. 62). It can only be hoped that the legal position will be clarified by the CJEU in its forthcoming decisions in these cases.
} 
the limits of the applicable provisions, which enjoy a presumption of validity. He concludes that the right to freedom of the arts as provided for in Art. 13 of the Charter does not require the recognition of an exception for the creation of new works along the lines of Sec. 24 of the German Copyright Act. ${ }^{5}$ Within this structure, fundamental rights are said to function as "a sort of ultima ratio which cannot justify departing from the wording of the relevant provisions except where there is a gross violation of the essence of a fundamental right." 6 An unwillingness to allow Charter arguments unduly to disturb the legislative scheme is understandable. However, the application of the Charter's principles need not be so disruptive. In Deckmyn, in interpreting the exception for the use of copyright works for the purpose of caricature, parody and pastiche under Art. $5(3)(\mathrm{k})$, the Grand Chamber emphasised the need to establish a "fair balance" between the rights protected under the Charter, including the freedom of expression of the user of the copyright work. By contrast, in interpreting the quotation exception narrowly in his Opinion, the Advocate General makes no reference at all to the need to secure a "fair balance" between competing rights, including those of the user of the sound recording at issue. Furthermore, in case C-145/10 Eva-Maria Painer, in considering the scope of Art. 5(3)(d) itself, the Court of Justice noted that the provision is intended to "strike a fair balance between the right to freedom of expression of users of a work or other protected subject matter and the reproduction right conferred on authors" and interpreted the exception accordingly. ${ }^{7}$ In the interest of the development of a predictable jurisprudence, it can be suggested that such a "fair balance" assessment should also have been conducted by the Advocate General in this case.

c) At the level of detail, there is also a difference between the approach adopted in this instance and the definition of the concepts at issue in Painer and Deckmyn. In both cases, the Court adopted an unrestricted definition of the terms at issue ("quotation" and "parody" respectively). In Deckmyn, as noted above, this definition was combined with a requirement upon national courts to apply the exception in accordance with a "fair balance" between competing rights. In his Opinion in Pelham $\mathrm{GmbH}$, the Advocate General takes a very different approach to the interpretation of the concept of "quotation for purposes such as criticism or review", suggesting that it is subject to (i) a requirement for interaction, (ii) a prohibition on alteration of the quoted subject matter and (iii) an obligation to distinguish the quoted element as a foreign element in the quoted work. These conditions are said to arise from the everyday meaning of the terms of Art. 5(3)(d). This approach is recklessly conservative. In reality, the concept of "quotation for purposes such as criticism or review" is much more contested than the Advocate General suggests. In the interests of

\footnotetext{
5 Case C-476/17 Pelham GmbH v. Hütter, Opinion of Advocate General Szpunar, 12 December 2018 EU:C:2018:1002, para. 96.

${ }^{6}$ Case C-476/17 Pelham GmbH v. Hütter, Opinion of Advocate General Szpunar, 12 December 2018 EU:C:2018:1002, para. 98.

${ }^{7}$ Case C-145/10 Eva Marie Painer v. Standard VerlagsGmbH et. al., 1 December 2011, EU:C:2018:798, paras. 134-137.
} 
(i) ensuring compliance with Art. 10(1), Berne Convention and (ii) retaining the legal flexibility to accommodate future cultural and technological developments, it might have been wiser to have allowed a more substantial role for the concepts of "fair balance" and "fair practice". 8

d) The suggested response to the referred questions is also in conflict with the national constitutional court's assessment of the fair balance between competing rights. It is true that the Federal Constitutional Court was concerned with a specific legislative context. As the Advocate General notes, the judgment of the Constitutional Court was "mainly based on the interpretation of Paragraph 24(1) of the [German Copyright Act] in the light of the freedom of artistic creation enshrined in the first sentence of Paragraph 5(3) of the Basic Law". " However, at a fundamental level, regardless of the positive legal framework at issue, the Court's considered view was that a body of rules that prohibits samplers from making use of very short extracts from sound recordings in the creation of new sound recordings constitutes an unjustified interference with the right to freedom of the arts.

e) Finally, and vitally, all copyright systems include mechanisms that provide a degree of flexibility. These allow, for example, the adjustment of legal structures to accommodate changing social expectations and unforeseen uses of protected forms. They function as limitations on the scope of exclusive rights, as flexibly interpreted exceptions or as applications of more general legal principles - and they arise just as much in civil law as in common law copyright jurisdictions. ${ }^{10}$ If the Advocate General's Opinion were to be followed, much of the potential to develop such flexibility within Union copyright law would be drained from the system. The Opinion envisages (i) an absolutely defined right of reproduction that captures even de minimis uses of works and other subject matter, (ii) narrowly defined legislative exceptions and (iii) a very limited potential for the adjustment of these rigid rules through the application of the principles enshrined in the Charter. The Advocate General clearly fears the threat of uncertainty to "good old property rights". "However, his proposed solutions unnecessarily risk stifling the development of Union copyright law at a relatively early stage in its development and seem unlikely to foster European cultural and technological development.

\section{Opinion of the European Copyright Society in Relation to the Pending Reference Before the CJEU in Case C-476/17, Hutter v. Pelham}

\section{Background}

[1.1] The reference arises from a long-running lawsuit in Germany which has already been considered by the Bundesgerichtshof (German Federal Supreme Court)

\footnotetext{
8 See Information Society Directive (Directive 2001/29/EC), Art. 5(3)(d).

9 Case C-476/17 Pelham GmbH v. Hütter, Opinion of Advocate General Szpunar, 12 December 2018 EU:C:2018:1002, para. 86.

10 See Hugenholtz and Senftleben (2011).

11 Case C-476/17 Pelham GmbH v. Hütter, Opinion of Advocate General Szpunar, 12 December 2018 EU:C:2018:1002, para. 5 .
} 
in 2008 and 2012 and the Bundesverfassungsgericht (German Federal Constitutional Court, Supreme Court in matters of constitutional law) in 2016.

[1.2] The underlying claim was brought by the iconic German electronic music pioneers, Kraftwerk. They asserted copyright and phonogram producer rights against the unauthorised use of a sound fragment of two seconds in a continuous rhythmic sequence of Sabrina Setlur's song "Nur mir". The sound fragment stemmed from the piece "Metall auf Metall" in Kraftwerk's 1977 album "Trans Europa Express". In "Nur mir", the sound fragment is slowed down (by 5\%) and repeated.

[1.3] In its first two decisions in the Metall auf Metall saga, ${ }^{12}$ the Federal Constitutional Court had held that sound sampling fell outside the scope of permitted free use (Art. 24 of the Urheberrechtsgesetz (German Copyright Act)) and amounted to infringement of the neighbouring right of the phonogram producer if the unauthorised user would have been able to produce the desired sound fragment him- or herself. ${ }^{13}$ In a further decision, the Court had specified that this criterion required an assessment of whether a sound producer with average equipment and talent, at the time of unauthorised use, would have been able to produce a recording which, from the perspective of the target audience, could be considered to be equivalent to the original sound fragment. ${ }^{14}$

[1.4] In its decision in this case, the Federal Constitutional Court held that the jurisprudence of the Federal Supreme Court, according to which in principle even smallest samples of phonograms reproduce a protected "part" of a phonogram and thus infringe the related rights of phonogram producers, was incompatible with the freedom of the arts as guaranteed by Art. 5(3), sentence 1, of the Grundgesetz. (German Basic Law). The Federal Constitutional Court found that there ought to be room for artistic sampling, and that neither the possibility of acquiring a licence ("Get a licence or do not sample") ${ }^{15}$ nor the freedom to imitate the sample by recording similar sounds provided adequate alternatives for the unauthorised reproduction, distribution and other use of samples for artistic purposes. ${ }^{16}$

[1.5] The Federal Constitutional Court also found that the criterion adopted by the Federal Supreme Court for the application of Art. 24 of the Copyright Act

\footnotetext{
12 For a more detailed discussion of the Metall auf Metall decisions in Germany, see Podszun (2016), p. 606; Leistner (2016).

13 Federal Supreme Court, Case I ZR 112/06, 20 November 2008, "Metall auf Metall I", 15, published in: Gewerblicher Rechtsschutz und Urheberrecht 2009, 403; and, in English, at (2009) 56 Journal of the Copyright Society of the USA pp. 1017, 1034.

14 Federal Supreme Court, Case I ZR 112/06, 20 November 2008, "Metall auf Metall I", 15, published in: Gewerblicher Rechtsschutz und Urheberrecht 2009, p. 403; and, in English, at (2009) 56 Journal of the Copyright Society of the USA 1017, 1034.

15 Cf. the US case of Bridgeport Music, Inc. v. Dimension Films, 410 F.3 d 792 (6th Cir. 2005); but see VMG Salsoul, LLC v. Ciccone, 824 F.3 d 871 (9th Cir. 2016).
}

${ }^{16}$ Federal Constitutional Court, Case 1 BvR 1585/13, 31 May 2016, ECLI:DE:BVerfG:2016:rs20160531.1bvr158513, Metall auf Metall, paras. 95 et seq. 
encroached upon the guarantee of free artistic expression because it created too much legal uncertainty. The Court expressed the fear that

even in cases where the production of an equivalent recording is not possible, artistic creators may refrain from use - even though this would be permissible according to the approach of the German Federal Supreme Court - because the effort necessary to provide evidence that there were no available means to produce the same sounds and the legal risk involved appear too big. The criterion based on the feasibility of producing an identical sound thus has a deterrent effect which requires a particularly efficient control in the light of constitutional law. ${ }^{17}$

As a result, the Court indicated that the deterrent effect that arises from legal uncertainty surrounding a permitted use must be factored into the assessment of its compatibility with basic rights.

[1.6] The Court did not, however, decide how this fair balance between the property interests and the artistic interests at stake in this case should be implemented doctrinally. Rather it left two possible options, which are now before the Court of Justice: either the freedom of artistic sampling is to be realised via a reading of the limitations and exceptions, in particular the quotation right, in light of the freedom of the arts (see infra, question 4), or that freedom is to be secured via a purposive reading of the exclusive rights of phonogram producers. ${ }^{18}$

[1.8] The Federal Supreme Court, in its order for reference, ${ }^{19}$

(i) reiterates its position, according to which the reproduction of even the smallest parts of a phonogram may amount to a reproduction in the sense of Art. 2(c) of Directive 2001/29/EC and Art. 9(1)(b) of Directive 2006/115/EC as even these smallest parts of the phonogram would represent the necessary investment of the producer;

(ii) states that the provision on permitted free uses (Art. 24 German Copyright Act), which is directly applicable only to copyright cases, could nevertheless be applied by analogy to the phonogram producer's right, so long as the new phonogram maintained a sufficient distance from the earlier protected phonogram;

(iii) argues that the limitations and exceptions provided under Art. 5 of Directive 2001/29 are not available to the defendant in these proceedings. The

\footnotetext{
${ }^{17}$ Federal Constitutional Court, Case 1 BvR 1585/13, 31 May 2016, ECLI:DE: BVerfG:2016:rs20160531.1bvr158513, Metall auf Metall, para. 100.

${ }^{18}$ Federal Constitutional Court, Case 1 BvR 1585/13, 31 May 2016, ECLI:DE: BVerfG:2016:rs20160531.1bvr158513, paras. 110-111 - Metall auf Metall.

${ }^{19}$ Federal Supreme Court, Case I ZR 115/66, 1 June 2017, "Metall auf Metall I", 15, published in: Gewerblicher Rechtsschutz und Urheberrecht 2017, pp. 895-900. For a detailed discussion of the order see Ohly (2017), pp. 964-969.
} 
requirements of "quotation" (Art. 5(3)(d)), "incidental inclusion" in another work (Art. 5(3)(i)) and/or "caricature, parody or pastiche" (Art. 5(3)(k)) are not met by the defendant's use in this instance;

(iv) concludes that the fundamental rights protected under the European Union's Charter of Fundamental Rights (CFR) (Arts. 17(2) and 13) do not justify a different decision in this case.

[1.9] Nevertheless, before coming to a final decision, the Federal Supreme Court decided to refer several questions to the CJEU. It did so, in particular because the exclusive rights of phonogram producers, as well as the limitations and exceptions to those rights, are harmonised by Directives 2001/29/EC and 2006/115/EC.

[1.10] The European Copyright Society, ${ }^{20}$ which is not funded by and has no connection with either party, comprises a group of scholars expert in European copyright law and offers here its view as to the appropriate answer to those questions.

2. Interpretation of Rights and Exceptions in the light of the Charter

\section{Question 6}

In what way are the fundamental rights set out in the CFR be taken into account when ascertaining the scope of protection of the exclusive right of the phonogram producer to reproduce (Art. 2(c) of Directive 2001/29/EC) and to distribute (Art. 9(1)(b) of Directive 2006/115/EC) its phonogram and the scope of the exceptions or limitations to those rights (Art. 5(2) and (3) of Directive 2001/29/EC and Art. 10(2), first sentence, of Directive 2006/115/EC)?

\section{Answer}

[2.1] EU secondary legislation must always be interpreted in a manner that ensures compatibility with the fundamental rights protected under the CFR. Under Art. 6(1) of the Treaty on the European Union (TEU), the Charter has equivalent status to the founding EU Treaties. Fundamental rights are therefore always relevant when the Court, or a Member State court, seeks to establish either (i) the scope of a phonogram producer's reproduction and distribution rights, or (ii) the scope of the exceptions or limitations to those rights.

[2.2] The Court has already recognised that the Charter rights are relevant to the interpretation of the scope of the exclusive rights provided for authors (Case C-160/ 15, GS Media BV ECLI:EU:C:2016:644, [44]-[46]) and to the interpretation and application of exceptions and limitations to those rights (C-201/13, Deckmyn ECLI:EU:C:2014:2132, [25]-[32]). ${ }^{21}$ Fundamental rights must also be relevant to

\footnotetext{
$\overline{20}$ www.europeancopyrightsociety.org.

21 See for more details on the interpretation of exceptions and limitations to copyright in accordance with the Charter, in particular freedom of expression, the previous Opinion of the European Copyright Society, "Limitations and Exceptions as Key Elements of the Legal Framework for Copyright in the European Union - Opinion of the European Copyright Society on the Judgment of the CJEU in Case C-201/13 Deckmyn (2015) 46 International Review of Intellectual Property and Competition Law, p. 93, https://doi. org/10.1007/s40319-015-0297-0; and www.europeancopyrightsociety.org.
} 
equivalent assessments in the case of protected rights related to copyright, including the rights of phonogram producers. In interpreting the legislative acquis on copyright and related rights, the Court has repeatedly noted the need to ensure a "fair balance" between competing rights (see, for example, C-275/06, Promusicae, ECLI:EU:C:2008:54; C-201/13, Deckmyn ECLI:EU:C:2014:2132 [27]).

[2.3] On facts such as those under consideration here, ${ }^{22}$ the most obviously relevant Charter rights are, in support of the phonogram producer, ${ }^{23}$ the right of property (including the right of intellectual property) (CFR, Art. 17) and, in support of the user of the phonogram, the freedom of the arts (CFR, Art. 13). The right of freedom of expression and information (CFR, Art. 11) supports the interests of both the user of the phonogram and the audience for the new musical work containing a sample from the phonogram. ${ }^{24}$ The scope of these rights is to be interpreted in accordance with equivalent rights in the European Convention on Human Rights and in accordance with constitutional traditions common to Member States. ${ }^{25}$

[2.4] In the national proceedings, the Federal Constitutional Court decided that a fair balance between competing rights would not be achieved through the application of a rule under which the unlicensed use of a very small sample of a phonogram would infringe the exclusive rights in that phonogram. In particular, it held that such a rule would violate the freedom of artistic activity under Art. 5 of the Grundgesetz (German Basic Law). An assessment of the "fair balance" between competing Charter rights in a case such as this leads us to conclude that the same outcome ought also to be reached in European Union law.

[2.5] Creative expression, encompassing the right to access creative expression, is protected under both Arts. 11 and 13 of the Charter. ${ }^{26}$ On facts such as those at issue here, those rights weigh heavily in the balance. The sampling of extracts from phonograms in the creation of new musical works is a contemporary cultural form of acknowledged significance. ${ }^{27}$ Valuable creative activity would be deterred if

\footnotetext{
${ }^{22}$ Questions relating to the nature of the relationship between the copyright acquis and the fundamental rights protected under the Charter have also been referred to the Court by the Federal Supreme Court in C-469/17 Funke Medien NRW GmbH (reference of 4 August 2017) and C-516/17 Spiegel Online (reference of 25 August 2017).

23 For the sake of clarity, it should be noted that the European Union's legal system also recognises distinctly the rights of the composer in the musical work, the rights of performers whose works are embodied in the recordings and national laws, while international laws require Member States to recognise the moral rights of composers (as authors) and performers. Here, the Court is solely concerned with the rights granted to phonogram producers.

24 Both the right holder in the phonogram and the person using the sample of the phonogram might conceivably also be entitled to rely on the right to conduct a business under Art. 16, CFR. However, such reliance would be unlikely to shift the balance between competing interests described below.

25 CFR, Art. 52(3), (4).

26 To date, limited guidance is available on the interpretation of the freedom of the arts under the CFR. See Peers et al. (2014), p. 380. On its scope in international, regional human rights instruments and in national constitutions, see Geiger (forthcoming 2018).

27 On the history of musical sampling (as well as its copyright implications), see the interesting early article by Szymanski (1996), p. 273; Duhanic (2016), pp. 1007, 1008 (as this author rightly puts it, "no sampling, no Hip Hop. And that would be unacceptable for a democratic society governed by the rule of
} 
(i) short samples could only be used with the permission of the right holder in the phonogram and/or (ii) samples had to be recreated ab initio by the user. In such circumstances, harm to the public interest in access to culture would result.

[2.6] By contrast, the phonogram producer's claim based on the right of property (including the right of intellectual property) under Art. 17 of the Charter is less compelling in this instance. The right of property must always be exercised in accordance with its social function. ${ }^{28}$ On facts such as those at issue here, the essence of the right of property is not affected. The right holder will suffer minimal, if any, economic harm as a result of the use of a very small extract from a protected phonogram as a sample in a subsequent musical work. Consequently, the Court should conclude that a fair balance between competing fundamental rights will only be secured if such sampling of very small extracts is permitted.

[2.7] On this basis, the Court can ensure compatibility with the Charter by (i) interpreting the scope of the rights of a phonogram producer as excluding their application in cases of sampling of short extracts and/or (ii) interpreting the quotation exception under Art. 5(3)(d) of Directive 2001/29/EC as covering such sampling activity. The former approach avoids a situation in which the user of a phonogram would be required to prove that the use of a very small extract is covered by an exception or limitation. In a situation in which the application of the Charter favours creative freedom, such an incidence of the burden of proof may be inappropriate. As indicated above, the Federal Constitutional Court highlighted the risk of legal uncertainty having a chilling effect on artistic creativity in this case. A solution based on a restrictive interpretation of the exclusive right of phonogram producers might have some advantages from this perspective. It relieves sound samplers of the legal uncertainty that may arise from the obligation to convince a judge of the applicability of an exception or limitation.

3. The Meaning of "Part" and "Copy"

\section{Questions 1 and 2}

Question 1: Is there an infringement of the phonogram producer's exclusive right under Art. 2(c) of Directive 2001/29/EC to reproduce its phonogram if very short audio snatches are taken from its phonogram and transferred to another phonogram?

[3.1] In the opinion of the Federal Supreme Court, the subject matter of the exclusive rights of the phonogram producer is not the phonogram itself but the economic, organisational and technical effort to produce the first fixation, in other

\footnotetext{
Footnote 27 continued

law and the resulting freedom for artists to express themselves artistically"); Arewa (2006), p. 547; Sanjek (1992), p. 607; Geiger supra note 26. For detailed studies, see Okpaluba (2000); McLeod and Di Cola (2011) (ethnographic study). For a discussion of different forms of sampling, see Morrison (2008), p. 75 .

${ }^{28}$ For further discussion of a limited nature of the right to property in general and intellectual property in particular, see Peukert (2015), p. 132; Griffiths and McDonagh (2013), p. 75; Geiger (2013), p. 153.
} 
words the investment in this product. ${ }^{29}$ Although this approach correctly identifies the purpose of the rights of phonogram producers, it is not in line with the clear wording of Art. 2(c) of Directive 2001/29/EC) and Art. 9(1)(b) of Directive 2006/115/EC. These provisions set out that Member States shall provide for the exclusive reproduction and distribution right "for phonogram producers, [in respect] of their phonograms". Correspondingly, Recital 10, second sentence, of Directive 2001/29/EC provides that the investment required "to produce products such as phonograms" is considerable. Thus, and in contrast to the sui generis (sic!) right for database producers, the related right of phonogram producers does not attach to the investment in the phonogram, but to the end product as such. ${ }^{30}$ The Federal Supreme Court therefore asks, in essence, what constitutes a protected "part ... of [a] phonogram" according to Art. 2(c) of Directive 2001/29/EC. This question resembles the issue posed in the Infopaq case with regard to protected parts of "works" under Art. 2(a) of Directive 2001/29/EC. ${ }^{31}$

[3.2] In providing a definition of a "part of a phonogram" in the sense of Art. 2(c) of Directive 2001/29/EC, the Court should take note of the provisions of international law. Neither the Rome Convention ${ }^{32}$ nor the WIPO Performers and Phonograms Treaty $^{33}$ refer to "partial" reproduction of phonograms. Rather, like the Berne Convention on authors' rights, ${ }^{34}$ the two Conventions leave the determination of the threshold of liability to Member States. Having said that, it is clear from the proceedings of the WIPO 1996 Treaty (where there was a proposal to introduce a right to control "modifications") that many Member States consider an infringement of the rights in a phonogram to occur only where there is a reproduction of a "substantial part" thereof. ${ }^{35}$

\footnotetext{
${ }^{29}$ Federal Supreme Court, Request for a preliminary ruling, Pelham GmbH and Others, Case C-476/17, para. 18.

${ }^{30}$ Art. 3(b) of the Rome Convention defines a phonogram as an exclusively aural fixation of sounds of a performance or of other sounds; while Art. 2(b) of the WIPO Performers and Phonograms Treaty defines a phonogram as either a fixation of sounds of a performance, or of other sounds or of a representation of sounds.

${ }^{31}$ Case C-5/08 Infopaq International, ECLI:EU:C:2009:465, [2009] ECR I-6569, paras. 30 et seq.; Leistner supra note 12, pp. 772 (775).

${ }^{32}$ Rome Convention for the Protection of Performers, Producers of Phonograms and Broadcasting Organisations, Art. 10 ("Producers of phonograms shall enjoy the right to authorise or prohibit the direct or indirect reproduction of their phonograms.") (at http://www.wipo.int/wipolex/en/treaties/text.jsp?file_ id=289757) During the Diplomatic Conference, a Belgian proposal explicitly to extend the wording of the reproduction right to cover partial reproduction was rejected.

${ }^{33}$ WIPO Performers and Phonograms Treaty, Art. 11 ("Producers of phonograms shall enjoy the exclusive right of authorizing the direct or indirect reproduction of their phonograms, in any manner or form.”) (at http://www.wipo.int/wipolex/en/treaties/text.jsp?file_id=295578).

${ }^{34}$ Ricketson and Ginsburg (2006), [11.26], p. 644 ("Berne does not dictate the standard for finding infringement. It does not instruct member states as to whether there is a threshold of substantiality that the defendant's copying must cross before it can be held liable.").

${ }^{35}$ Records of the Diplomatic Conference on Certain Copyright and Neighbouring Rights, Geneva 1996 (Geneva: WIPO, 1999), Vol 2, p. 665, [228], [230], [232], [235] (discussion of proposed Arts. 8 and 15, 9 December 1996).
} 
[3.3] Nevertheless, the Geneva Phonograms Convention (GPC), to which most EU Member States are bound, offers some guidance. ${ }^{36}$ According to Art. 2 of the GPC, each Contracting State shall protect producers of phonograms who are nationals of other Contracting States against the making of duplicates without the consent of the producer and against the importation of such duplicates, provided that any such making or importation is for the purpose of distribution to the public, and against the distribution of such duplicates to the public. The crucial notion of "duplicate" is defined in Art. 1(c) of the GPC as follows:

For the purposes of this Convention, "duplicate" means an article which contains sounds taken directly or indirectly from a phonogram and which embodies all or a substantial part of the sounds fixed in that phonogram. ${ }^{37}$

While it is true that Art. 7(1) GPC proclaims that the GPC shall in no way be interpreted as limiting or prejudicing the protection otherwise secured to producers of phonograms under any domestic law, the Court of Justice should, for the following reasons, interpret "part ... of a phonogram" in light of Art. 1(c) of the GPC.

[3.4] Firstly, the GPC attaches, like EU copyright law, to the phonogram and thus the fixation of sounds (and not the investment). Secondly, using Art. 1(c) GPC as a point of reference guarantees that EU copyright law is interpreted in conformity with relevant international law. ${ }^{38}$ Thirdly, the application of the GPC threshold of "substantiality" would allow the Court of Justice to subject the related right of phonogram producers, like any other intellectual property right, including in particular copyright, to a minimum requirement of protection that reflects the purpose of the respective right. ${ }^{39}$ Derogations from the principle of free movement and limitations on the exercise of fundamental rights (such as the freedom of the arts) through intellectual property rights are permitted only to the extent that they are justified for the purpose of safeguarding the specific subject matter of the

\footnotetext{
36 Convention for the Protection of Producers of Phonograms Against Unauthorized Duplication of Their Phonograms (1971), http://www.wipo.int/wipolex/en/treaties/text.jsp?file_id=288582\#P61_6005.

37 Federal Supreme Court, Request for a preliminary ruling, Pelham GmbH and Others, Case C-476/17, para. 16. See further "Report Presented by the General Rapporteur", para. 40, in Records of the International Conference of States on the Protection of Phonograms, Geneva, October 18 to 29, 1971 (WIPO/UNESCO, 1975), pp. 35, 38 (substantiality expresses a qualitative, not just a quantitative, assessment; in this respect "quite a small part may be substantial"); Commentary on the Draft Convention (adopted by the Committee of Governmental Experts), Phon.2/4, [55], ibid, pp. 159, 167 (giving as example a part comprising a whole track); Summary Minutes (Main Commission), paras. 668-688.1 in ibid, 74, at 101-103 (discussing the draft text, and adopting the term "substantial" to ensure the reproduction of a track from an LP was covered) and 918.3, 923-937 at pp. 126-127 (deciding not to re-open discussion of the requirement of substantiality); WIPO Guide to the Rome Convention and Phonograms Convention (Geneva: WIPO, 1981), pp. 97-98 (accessible online at http://www.wipo.int/ edocs/pubdocs/en/copyright/617/wipo_pub_617.pdf) ("national laws and courts have the final decision when a sufficient part is taken to make this damage a reality.").

38 Federal Constitutional Court, Case 1 BvR 1585/13, 31 May 2016, ECLI:DE:BVerfG:2016:rs20160531.1bvr158513, para. 111 - Metall auf Metall.

39 V. Ungern-Sternberg (2014), pp. 209 (216); Hoeren, MMR 2009, pp. 253 (257); contra Federal Supreme Court, Request for a preliminary ruling, Pelham GmbH and Others, Case C-476/17, para. 19.
} 
intellectual property concerned. A right holder is not guaranteed the opportunity to demand the highest possible remuneration. ${ }^{40}$ To this end, the Court could extrapolate from its jurisprudence regarding Art. 7(1) of the Database Directive. ${ }^{41}$ While the points of attachment of the sui generis right in databases and the related rights of phonogram producers differ (investment v. phonogram), the purpose of both rights is the same: databases like phonograms require substantial investment, and the possibility of recouping that "especially high and risky" investment can be effectively guaranteed only through adequate legal protection of the right holders concerned. ${ }^{42}$ According to Art. 7(1) of the Database Directive, 96/9/EC, "Member States shall provide for a right for the maker of a database which shows that there has been qualitatively and/or quantitatively a substantial investment in either the obtaining, verification or presentation of the contents." As the Court held in The British Horseracing Board Ltd and Others, this threshold implies "significant human, technical or financial investment". 43

[3.5] In contrast to the suggestion of the Federal Supreme Court in its request for a preliminary ruling, every sample of a phonogram does not automatically represent a quantitatively or qualitatively substantial investment in the aforementioned sense. ${ }^{44}$ In the light of the available digital technologies for the recording and mixing of audio tracks, it is factually incorrect to assume that every independently recorded audio track, let alone a two second sound sample of such an audio track, requires significant human, technical or financial investment. Whether that is so depends upon the circumstances of the case, taking into account both the plaintiff's and the defendant's phonogram.

[3.6] Furthermore, Art. 7(1) of the Database Directive demonstrates that the requirement of a "substantial investment" not only informs the decision whether a part of a phonogram qualifies for protection in the first place, but also the scope of the rights in a protected phonogram. An extraction and/or re-utilisation of the contents of a protected database will infringe only if this use concerns "the whole or ... a substantial part, evaluated qualitatively and/or quantitatively, of the contents of that database" (Database Directive, 96/9/EC, Art. 7.1). As the Court of Justice has explained, a user extracts and/or re-utilises such a quantitatively or qualitatively significant part of the contents of a database "if the investment in the extracted or re-utilised part is, proportionately, ... substantial". 45 If the rules that have evolved in the field of database protection are taken as a reference point for dealing with the

\footnotetext{
${ }^{40}$ CJEU Joined cases C-403/08 and C-429/08, Football Association Premier League and Karen Murphy, ECLI:EU:C:2011:631, paras. 106, 108.

${ }^{41}$ Ohly supra note 19, pp. 964 (966).

42 Directive 96/9/EC, Recital 40; Directive 2001/29/EC, Recitals 4 s. 1, 10 s. 2; Directive 2006/115, Recital 5.

${ }^{43}$ Case C-203/02, The British Horseracing Board Ltd and Others v. William Hill Organization Ltd [2004] ECR I-10415, para. 71.

${ }^{44}$ Contra Federal Supreme Court, Request for a preliminary ruling, Pelham GmbH and Others, Case C-476/17, para. 18 .

${ }^{45}$ Case C-203/02, The British Horseracing Board Ltd and Others v. William Hill Organization Ltd [2004] ECR I-10415, paras. 69-71.
} 
corresponding question of protecting investment in a phonogram, it may be said that a protected phonogram is reproduced in part only if the copying free-rides on a substantial investment. It is thus mistaken to automatically equate a short sample with the complete phonogram. ${ }^{35}$ Again, everything depends upon the circumstances of the case.

[3.7] The approach advocated by the Federal Supreme Court also ignores the concrete effects of the sample on the protected interests of the phonogram producer in the case at hand and thus fails to take into account the purpose of the related right in question. This purpose is only affected if a reproduction and/or distribution of a part of a phonogram prevents the phonogram producer from recouping a substantial investment. ${ }^{46}$ In this regard, the Federal Constitutional Court, in its decision in this case of 31 May 2016, required a finding that the use of the sample significantly prejudiced the economic interests of the phonogram producer by threatening to reduce the number of sales/licenses of the original. ${ }^{47}$ This, in turn, is only the case if the sample substitutes for the original phonogram. ${ }^{48}$

[3.8] Because such a substitutive effect will be rare in the case of a short sample, a purposive interpretation of the concept of "part" of a "phonogram" will also ensure that a fair balance is struck between the fundamental right to intellectual property (CFR, Art. 17(2) CFR) and the fundamental right to artistic freedom (CFR, Art. 13 first sentence).

[3.9] Sampling ought to encroach upon the exclusive rights of a phonogram producer only if it significantly prejudices the economic interests of the right holder, i.e. if it prejudices the prospect of recouping a substantial investment in the production of the phonogram through substitution of the original. ${ }^{49}$

Question 2

Is a phonogram which contains very short audio snatches transferred from another phonogram a copy of the other phonogram within the meaning of Art. 9(1)(b) of Directive 2006/115/EC?

[3. 10] See answer to question 1.

4. The Scope of the Quotation Exception

Question 4

\footnotetext{
46 Supra note 31 (recitals).

47 Federal Constitutional Court, Case 1 BvR 1585/13, 31 May 2016, ECLI:DE:BVerfG:2016:rs20160531.1bvr158513, paras. 101 et seq. - Metall auf Metall.

48 Ohly supra note 19, pp. 964 (966).

49 Federal Constitutional Court, Case 1 BvR 1585/13, 31 May 2016, ECLI:DE: BVerfG:2016:rs20160531.1bvr158513, para. 110 - Metall auf Metall; Hanseatisches Oberlandesgericht, Case 3 W 38/91, GRUR Int. 1992, pp. 390 (391); Hanseatisches Oberlandesgericht, Case 3 U 237/90, NJW-RR 1992, pp. 746 (748); Gelke (2013), pp. 128 et seq.; Häuser (2002), p. 109 et seq.; Leistner (2014), pp. 846 (849); Salagean (2008), p. 231 et seq.
} 
Can it be said that a work or other subject matter is being used for quotation purposes within the meaning of Art. 5(3)(d) of Directive 2001/29/EC if it is not evident that another person's work or another person's subject matter is being used?

Answer:

[4.1] Under Art. 5(3)(d), Member States may provide for an exception to the author's exclusive right of reproduction of his work in respect of

(i) quotations for purposes such as criticism or review, provided that

(ii) they relate to a work or other subject matter which has already been lawfully made available to the public;

(iii) their use is in accordance with fair practice, and to the extent required by the specific purpose.

(iv) the source, including the author's name, is indicated, unless this turns out to be impossible.

[4.2] The terms of the provision reflect those of Art. 10(1) of the Berne Convention. However, while the provision is presented as optional for Member States, it is important to observe that under Art. 10(1) of that Convention, an exception for use in quotation is mandatory for members of the Berne Union. ${ }^{50}$ Indeed, in the travaux to the Stockholm Revision of Berne (when Art. 10(1) was introduced), the provision is commonly described as the quotation right. ${ }^{51}$

[4.3] As already observed, one key aim of Art. 10(1) and Art. 5(3)(d) is to ensure that the copyright system acts as an engine of, rather than an impediment to, freedom of expression. It is therefore important for the exception to be interpreted and applied in the light of Arts. 11 and 13 of the Charter. ${ }^{52}$ Freedom of expression requires that authors are free to use pre-existing materials where such use is proportionate to the aim pursued and in accordance with fair practice.

[4.4] As a result, the restrictive approach to the interpretation of exceptions and limitations first adopted in C-5/08 Infopaq International A/S v. Danske Dagblades

\footnotetext{
${ }^{50}$ On face value, the Article creates an obligation on Members of the Union to permit quotation in cases where the conditions are met. It states that "it shall be permissible ..." [emphasis added]. The use of the word "shall" in this context is imperative. Article 10(1) uses quite different language from that used in other provisions concerning exceptions. For example, Art. 10(2) states, in relation to exceptions for education, that "it shall be a matter for legislation in the countries of the Union ... to permit ...". Similar language is found in Art. $10^{\text {bis }}$ in relation to reporting current events and Art. 9(2), which allows exceptions to the reproduction right "in certain special cases". The language of Art. 10(1) is distinct, and clearly reads as mandatory rather than permissive. See Ricketson and Ginsburg (2006), pp. 788-789, [13.42]; Goldstein and Hugenholtz (2010) p. 379, [11.4.1]; Dinwoodie and Dreyfuss (2012), p. 185 (“a mandatory quotation right"); Xalabarder (2009).

${ }^{51}$ WIPO, Records of the Intellectual Property Conference of Stockholm, June 11 to July 14, 1967, Vol I, (WIPO, 1971) p. 116 (BIRPI Study Group), 117 (Document S/1, "Proposals for Revising the Substantive Copyright Provisions, Arts. 1-20 (Prepared by the Government of Sweden with the Assistance of BIRPI)").

${ }^{52}$ See European Copyright Society, "Limitations and Exceptions as Key Elements of the Legal Framework for Copyright in the European Union - Opinion of the European Copyright Society on the Judgment of the CJEU in Case C-201/13 Deckmyn", supra.
} 
Forening ECLI:EU:C:2009:465 56-58 cannot prevail in circumstances in which the use of a work is protected by a fundamental right under the Charter, such as Arts. 11 or 13.

[4.4] The only occasion on which the CJEU has examined the operation of Art. 5(3)(d) to date was in its first Judgment in Case C-145/10, Eva-Maria Painer v. Standard VerlagsGmbH, ECLI:EU:C:2011:798. ${ }^{53}$ In that Judgment, the Court treated Art. 5(3)(d) as requiring a balancing of the rights of owner and users:

[132] As regards the context surrounding Art. 5(3)(d) of Directive 2001/29, it is important to note that, as stated in recital 31 in the preamble to that directive, a "fair balance" must be safeguarded between, on the one hand, the rights and interests of authors, and, on the other, the rights of users of protected subject matter. ...

[134] Art. 5(3)(d) of Directive 2001/29 is intended to strike a fair balance between the right to freedom of expression of users of a work or other protected subject matter and the reproduction right conferred on authors.

[4.5] Neither the Directive nor the Berne Convention offer a definition of "quotation". Accordingly, the word should be given its ordinary meaning, taking into account the context in which it occurs. One important aspect of that context is that the right to quote is not limited to particular cultural genres. Art. 5(3)(d) applies to all works and subject matter of related rights, just as Art. 10(1) of Berne applies to all works. ${ }^{54}$ The significance of this is that the right to quote is not limited to the quotation of text or in text. Print-based paradigms of quotation should not be the sole consideration when interpreting the concept of quotation.

[4.6] Discussion of the re-use of music, art, architecture and film as "quotation" is very common. ${ }^{55}$ For this case, it is important to observe that the term "quotation" is also widely used to refer to the re-use of recordings of music. ${ }^{56}$ Digital sound sampling has often been described as "quotation". 57

\footnotetext{
53 [2011] ECR I-12533, [2012] ECDR (6) 89 (ECJ, Third Chamber).

54 Opening the discussion in Main Committee I at the intergovernmental Conference on June 16, 1967, Cavin, the Swiss representative, said his delegation approved the principle of extending the right of quotation to "all the categories of protected works": Minutes, para. 761, in WIPO, Records of the Intellectual Property Conference of Stockholm, June 11 to July 14, 1967, Vol I, (WIPO, 1971) 860. Later, George Straschnov objected to a proposal to limit the exception to "short" quotations on the basis that this would raise particular problems in relation to the quotation of artistic works, where moral rights would be implicated if only part was used: Minutes, para. [769], Records, p. 861.

55 See, for example, the recent special issue, (2014) 33(2) Contemporary Music Review on Music Borrowing and Quotation.

56 One example is Vladimir Ussachevsky's re-use of a recording of a 1951 performance of Wagner's Parsifal in his avant-garde sound collage, entitled Wireless Fantasy (1960) (Available via YouTube: https://www.youtube.com/watch?v=bEShy2QIj4U (accessed 23 September 2017)), which combined the performance with the sounds of Morse-code signals being tapped out. See Beaudoin (2007), pp. 143-151, esp. pp. 147-149.

57 Katz (2010), pp. 140-141 (referring to sampling as "performative quotation", that is, "quotation that recreates all the details of timbre and timing that evoke and identify a unique sound event"); HolmHudson (1997), p. 17 (describing digital sampling as "timbral quotation" and explaining that "the sample
} 
[4.7] In the paradigmatic case of textual quotation in another text, the convention is to distinguish the quoted material from the quoting material. This is done using quotation marks, insetting, and other devices. However, given that the right to quote applies to all material encompassed by authors' rights and related rights, it is inappropriate to import such conventions into the definition of "quotation". Otherwise, the meaning of quotation in Art. 5(3)(d) would not comport with its use as a description of practices of textual re-use in other cultural sectors, such as art, film, music and recorded music. Instead, the use of conventional devices such as "quotation marks" to delineate quoted text is more readily incorporated through the condition that permitted quotation must accord with "fair practice" and/or that the source, including the author's name, must be indicated, unless this turns out to be impossible.

[4.8] As a result, the answer to Question 4 is that a work may be used for quotation purposes within the meaning of Art. 5(3)(d) of Directive 2001/29/EC even if it is not evident that another person's work or another person's subject matter is being used. To satisfy the requirement to indicate an author's name, it is sufficient to include relevant information - to the extent that this is possible ${ }^{58}$ - in the description of the derivative work in which the pre-existing source material has been incorporated.

5. Harmonisation and Freedom of Member States in Implementing the Directive

\section{Question 5}

Do the provisions of EU law on the reproduction right and the distribution right of the phonogram producer (Art. 2(c) of Directive 2001/29/EC and Art. 9(1)(b) of Directive 2006/115/EC) and the exceptions or limitations to those rights (Art. 5(2) and (3) of Directive 2001/29/EC and Art. 10(2), first sentence, of Directive $2006 / 115 / E C$ ) allow any latitude in terms of implementation in national law?

\section{Answer}

[5.1] We do not think it necessary in these proceedings to answer these questions in the abstract or categorically, as the answers to the previous questions should be sufficient to determine the proceedings. However, we offer some tentative guidance.

With respect to the rights in Arts. 2 and 4

[5.2] In accordance with precedent, it is clear that the concepts of "reproduction" and "distribution" are autonomous concepts of European law. The Court has consistently held that the need for uniform application of EU law and the principle of equality demand that the terms of a provision of EU law which makes no express reference to the law of the Member States for the purpose of determining its

\section{Footnote 57 continued}

functions as a quote that is recontextualized but that nevertheless bears the weight of its original context"); Lacasse (2000), Ch 2 (describing sampling as a type of "autosonic quotation").

58 As to collage sampling which includes a wide variety of sound "snippets", see Morrison (2008), p. 75. Arguably, collage sampling using a very high number of pre-existing sounds is an example of a derivative work where the indication of the name of the authors of all source material "turns out to be impossible" in the sense of Art. 5(3)(d). 
meaning and scope must normally be given an autonomous and uniform interpretation throughout the European Union, having regard to the context of the provision and the objective pursued by the legislation in question. See, for example, C-467/08, Padawan, EU:C:2010:620, [32].

[5.3] The effect is that Member States are not permitted to deviate from the terms of those provisions: Case C-466/12, Svensson, ECLI:EU:C:2014:76, [33]-[41] (on Direcive 2001/29/EC, Art. 3).

[5.4] However, as already noted, it is also clear that the interpretation and application of these provisions must take account of the Charter. Responsibility for providing guidance as to such interpretation lies ultimately with the CJEU, but applying the provisions is a matter for the courts of the Member States.

[5.5] The responsibility for so ensuring interpretation and application in line with the Charter lies not just with the CJEU but also with the courts of Member States. In Case C-275/06, Promusicae [2008], ECLI:EU:C:2008:54, at para. 70, the CJEU stated that

when implementing the measures transposing ... directives, the authorities and courts of the Member States must not only interpret their national law in a manner consistent with those directives but also make sure that they do not rely on an interpretation of them which would be in conflict with those fundamental rights or with the other general principles of Community law, such as the principle of proportionality.

Art. 5(2), (3) (Exceptions and Limitations)

[5.6] In most instances, Member States have the choice whether to implement the optional exceptions, but the list of such exceptions is exhaustive: Member States may not maintain any other exceptions or limitations. See Directive 2001/29/EC, Recital 32.

[5.7] However, as already noted, at least Art. 5(3)(d) of the Directive is mandatory as a matter of international law on authors' rights (Berne Convention, Art. 10(1)). The interpretation and application of EU provisions must be in compliance with such international obligations (SGAE/Rafael hotels, ECLI:EU:C:2006:764, [2006] ECR I-11519 paras. 35, 40, 41 and Case C-403/08 and Case C-429/08, Football Association Premier League and Karen Murphy, ECLI:EU:C:2011:631, [2011] ECR I-9083, para. 189).

[5.8] In the case of optional exceptions, the freedom that is left to Member States varies from provision to provision. Some exceptions seem to envisage some freedom, others do not.

[5.9] In some cases, Member States do have limited freedom as to the implementation of an exception. The clearest example is Art. 5(3)(o), which allows for exceptions in cases of "minor importance" provided they only concern "analogue uses." Another is Art. 5(3)(e). In Case C- 145/10, Eva-Maria Painer v. Standard VerlagsGmbH, ECLI:EU:C:2011:798, the Court (para. 101) noted that the 
provisions of Directive 2001/29/EC do not expressly address the circumstances in which the interests of public security can be invoked with a view to the use of a protected work and, therefore, that "the Member States which decide to enact such an exception enjoy a broad discretion in that respect ...". It added that "such a discretion is, first, in accordance with the idea that each Member State is best placed to determine, in accordance with its national needs, the requirements of public security, in the light of historical, legal, economic or social considerations specific to it" [102].

[5.10] In Case C-462/09, Stichting de Thuiskopie, the Court, considering Art. $5(2)(b)$, stated (para. 23) that:

With regard to the answer to the question of the identification of the person who must be regarded as responsible for paying the fair compensation, the provisions of Directive 2001/29 do not expressly address the issue of who is to pay that compensation, meaning that the Member States enjoy broad discretion when determining who must discharge that obligation.

[5.10] In other cases, no such freedom exists: Case C-510/10, DR, TV2 Danmark A/S v. NCB-Nordisk Copyright Bureau, EU:C:2012:244, para. 36. In C-201/13, Deckmyn ECLI:EU:C:2014:2132, para. 16, the CJEU stated

An interpretation according to which Member States that have introduced that exception are free to determine the limits in an unharmonised manner, which may vary from one Member State to another, would be incompatible with the objective of that directive.

[5.11] Even where some "latitude" exists, principles of European law should inform the exercise of discretion: Opinion 3/15, (Marrakesh Opinion), ECLI:EU:C:2017:114, paras. 122-127 (ECJ, Grand Chamber). These include the need to safeguard the hierarchy of norms and to ensure compliance with fundamental rights (C-275/06, Promusicae, ECLI:EU:C:2008:54, para. 70), as well as compliance with international obligations.

\section{Question 3}

Can the Member States enact a provision which - in the manner of Sec. 24(1) of the Gesetz über Urheberrecht und verwandte Schutzrechte (German Law on Copyright and Related Rights) - inherently limits the scope of protection of the phonogram producer's exclusive right to reproduce (Art. 2(c) of Directive 2001/29/EC) and to distribute (Art. 9(1)(b) of Directive 2006/115/EC) its phonogram in such a way that an independent work created in free use of its phonogram may be exploited without the phonogram producer's consent?

[6.1] As we will explain, we treat this question last because we consider it unnecessary to determine the question in these proceedings.

[6.2] We begin by reminding the Court that it is being asked to consider the interpretation of two Directives. According to Art. 288 of the Treaty on the Functioning of the European Union, a Directive is binding "as to the result to be 
achieved", leaving to Member States "the choice of form and methods." It thus seeks to respect national traditions and approaches to structure, categorisation, form and interpretation. What is important is the result.

[6.2] Question 3 concerns a particularity of German and Austrian copyright law in its relation to the EU copyright acquis, namely the provision on "free use" in Art. 24 of the German Copyright Act and Art. 5(2) of the Austrian Copyright Act. ${ }^{59}$ Dutch copyright law sets forth a similar rule in Art. 13 of the Copyright Act, namely that adaptations constituting a new, original work fall outside the scope of the right of adaptation. ${ }^{60}$ According to Art. 24(1) of the German Act, an independent work created in the free use of the work of another person may be published or exploited without the consent of the author of the work used. Paragraph two sets out that the rule on "free use" shall not apply to the use of a musical work in which a melody is recognisably taken from the work and used as the basis for a new work. As follows from the wording and the context of Art. 24 of the German Copyright Act, which forms part of a subchapter on the exploitation rights of an author, the provision regulates the "free use" of works, not the free use of phonograms and other subject matter of related rights. The Federal Supreme Court is of the opinion, however, that Art. 24(1) German Copyright Act can be applied by analogy to the related right of phonogram producers. ${ }^{61}$ It is therefore worth emphasising from the outset that the answer of the Court of Justice to this question will have implications for copyright and related rights other than the rights of phonogram producers under German law.

[6.3] In assessing question 3, it is furthermore important to note that Art. 24(1) of the German Copyright Act is applied by German courts in two separate categories of cases, and that question 3 only concerns one of those, namely the situation where a copyright work has been made use of merely as an inspiration for another expression, which is so different in its outer appearance from the original that the expression of the original work has faded ("äußerer Abstand, verblassen"). ${ }^{62}$ It is this classical doctrine of "free use" that the Federal Supreme Court refers to in paragraphs 22 to 27 of its referral decision. ${ }^{63}$ In applying the doctrine in this case, the Federal Supreme Court is of the opinion that the musical piece "Nur mir" has individual features of its own which depart from the two-second sample copied from the 1977 Kraftwerk phonogram to such an extent that "Nur mir" is to be considered

\footnotetext{
${ }^{59}$ As to the application of this Austrian free-use rule in the light of fundamental rights and freedoms, see, for instance, Oberster Gerichtshof (Austrian Supreme Court), 13 July 2010, case 4 Ob 66/10z, "Lieblingshauptfrau".

${ }^{60}$ For a more detailed discussion of the Dutch provision, see Senftleben (2012), p. 359.

${ }^{61}$ Federal Supreme Court, Request for a preliminary ruling, Pelham GmbH and Others, Case C-476/17, para. 24.

${ }^{62}$ The other category concerns use for the purpose of caricature, parody or pastiche, and thus cases of Art. 5(3)(k) Directive 2001/29; see Federal Supreme Court, Request for a preliminary ruling, Pelham GmbH and Others, Case C-476/17, paras. 38-39, and infra.

${ }^{63}$ Federal Supreme Court, Request for a preliminary ruling, Pelham GmbH and Others, Case C-476/17, paras. 22-27.
} 
an "independent creation" under Art. 24(1) of the Copyright Act, as applied by analogy to phonograms. ${ }^{64}$

[6.4] The obvious problem with this reasoning is that it compares, on the one hand, the defendant's complete piece of music with, on the other hand, the two-second excerpt from the plaintiffs' phonogram. International, EU and German copyright laws do not operate, however, on the basis of a holistic concept of a "piece of music". Instead, they strictly distinguish between musical works (the composition), literary works (the lyrics), the performance of vocalists and instrumentalists, the phonogram on which all these expressions have been fixed, and the respective copyrights and related rights therein. The musical composition, the lyrics, and most of the performances fixed on the phonogram of the defendant do not reproduce or otherwise use the two-second sample at stake in the case. As such, these creative expressions do not encroach upon the exclusive rights of the plaintiffs "in their phonograms" (cf. Art. 2(c) of Directive 2001/29/EC) and Art. 9(1)(b) of Directive 2006/115/EC) because they do not incorporate parts of the original phonogram.

[6.5] What the Federal Supreme Court therefore asks, in essence, is whether the aforementioned distinction between works, performances, and fixed sounds remains valid if the combined fixation of all those independent subject matters includes a fragment of another phonogram that, in the overall impression of the piece of music and its artistic features, plays such a subordinate role that the creative expression of the derivative work clearly supersedes the creative expression of the incorporated fragment and, as a result, can be deemed independent and "free". On its merits, this "free use" privilege requires the derivative work to have new features of its own that make the individual features of the incorporated source material fade away. ${ }^{65}$ If the claimants were entitled to injunctive relief and further remedies as regards the reproduction and distribution of the song "Nur mir", they would be entitled, on the mere basis of their rights in their phonogram, to authorise or prohibit the use of musical compositions, lyrics, performances and (parts of) phonograms that make no use of their protected subject matter whatsoever. It is this kind of overreach that Art. 24(1) of the German Copyright Act as applied by the Federal Supreme Court is meant to prevent. Such a "free use" of a phonogram is a use that does not reproduce or distribute protected parts of a phonogram because it displays so many individual, expressive features of its own that the taking from pre-existing source material is no longer discernible.

[6.6] In our view, this reading of German copyright law is in line with Art. 2(c) of Directive 2001/29/EC and Art. 9(1)(b) of Directive 2006/115/EC because the scope of protection of the phonogram producer's exclusive rights is inherently limited to uses of this particular phonogram, i.e. the (partial) reproduction of this fixation and the use of those reproductions.

\footnotetext{
${ }^{64}$ Federal Supreme Court, Request for a preliminary ruling, Pelham GmbH and Others, Case C-476/17, para. 26.

65 For a more detailed discussion of this free use privilege against the background of international obligations, see Geller (2010), p. 901.
} 
This inherent limitation of the exclusive rights follows both from the wording and purpose of Art. 2(c) of Directive 2001/29/EC and Art. 9(1)(b) of Directive 2006/115/EC, which attach to phonograms and aim at protecting the investment necessary for their production (see infra, questions 1 and 2). These rights do not entitle the phonogram producer to authorise or prohibit the creation and exploitation of independent works, performances, and fixations of sounds. This is true irrespective of the fact that these objects are combined with a partial reproduction of a protected phonogram. Rightly understood, the German rule of "free" use, therefore, is a means of identifying forms of use which fall outside the scope of the aforementioned exclusive rights from the outset.

[6.7] Whether such a partial reproduction of a protected phonogram and the distribution of this reproduction as part of another song infringe the rights of the phonogram producer is thus a question which only arises if the taking has been substantial enough to remain a discernible, individual feature of the derivative work. In cases where the expressive features of the derivative work are sufficiently strong to make the features of an incorporated sound fragment fade away, however, the unauthorised taking does not reach a level of intensity that justifies the invocation of the exclusive right. Only if the derivative work does not have sufficiently strong features of its own is the taking substantial, and the assessment of infringement depends upon whether the sample constitutes a separately protected part of a phonogram (questions 1 and 2) and, if yes, whether the reproduction and distribution of this sample is subject to a limitation or exception under Art. 5 of Directive 2001/29/EC and Art. 10 of Directive 2006/115/EC (question 4). We have already considered those matters.

Members of the European Copyright Society Signatories of the Opinion:

- Prof. Valérie-Laure Benabou, Professeur, Université Aix Marseille

- Prof. Lionel Bently, Professor, University of Cambridge, United Kingdom

- Prof. Estelle Derclaye, Professor of Intellectual Property Law, University of Nottingham, United Kingdom

- Prof. Thomas Dreier, Director, Institute for Information and Economic Law, Karlsruhe Institute of Technology (KIT), Germany

- Prof. Séverine Dusollier, Professor, School of Law, SciencesPo, Paris (France), and Centre de Recherche Information, Droit et Société (CRIDS), University of Namur (Belgium)

- Prof. Christophe Geiger, Director, Centre d'Etudes Internationales de la Propriété Intellectuelle (CEIPI), University of Strasbourg, France

- Prof. Jonathan Griffiths, Professor of Intellectual Property Law, School of Law, Queen Mary University of London, United Kingdom

- Prof. Reto Hilty, Director, Max Planck Institute for Innovation and Competition, Munich, Germany

- Prof. P. Bernt Hugenholtz, Director, Institute for Information Law, University of Amsterdam, Netherlands

- Prof. Marie-Christine Janssens, Professor of Intellectual Property Law, University of Leuven, Belgium 
- Prof. Martin Kretschmer, Professor of Intellectual Property Law, University of Glasgow; and Director, CREATe, United Kingdom

- Prof. Axel Metzger, Professor of Civil and Intellectual Property Law, Humboldt-Universität Berlin

- Prof. Alexander Peukert, Goethe-Universität Frankfurt am Main, Germany

- Prof. Marco Ricolfi, Chair of Intellectual Property, Turin Law School, Italy

- Prof. Thomas Riis, Professor, Centre for Information \& Innovation Law, University of Copenhagen, Denmark

- Prof. Ole-Andreas Rognstad, Professor of Law, Department of Private Law, University of Oslo, Norway

- Prof. Martin Senftleben, Professor of Intellectual Property, VU University Amsterdam, Netherlands

- Prof. Alain Strowel, Professor, UCLouvain and Université Saint-Louis, Belgium

- Prof. Tatiana Synodinou, Professor, University of Cyprus

- Prof. Raquel Xalabarder, Chair on Intellectual Property, Universitat Oberta de Catalunya, Barcelona, Spain

Open Access This article is distributed under the terms of the Creative Commons Attribution 4.0 International License (http://creativecommons.org/licenses/by/4.0/), which permits unrestricted use, distribution, and reproduction in any medium, provided you give appropriate credit to the original author(s) and the source, provide a link to the Creative Commons license, and indicate if changes were made.

\section{References}

Arewa OB (2006) From JC Bach to hip hop: musical borrowing copyright and cultural context. N C Law Rev 84:547

Beaudoin R (2007) Counterpoint and quotation in Ussachevsky's wireless fantasy. Organ. Sound 12(2):143-151

Dinwoodie GB, Dreyfuss RC (2012) A neo-federalist vision of TRIPS. OUP, Oxford

Duhanic I (2016) Copy this sound! The cultural importance of sampling for hip hop music in copyright law - a copyright law analysis of the sampling decision of the German Federal Constitutional Court. GRUR Int 11:1007-1008

Geiger C (2013) The social function of intellectual property rights, or how ethics can influence the shape and use of IP law. In: Dinwoodie G (ed) Intellectual property law: methods and perspectives

Geiger C (forthcoming 2018) Freedom of artistic creativity and copyright law: a compatible combination? Centre for International Intellectual Property Studies Research Paper No. 2017-08; 8/3 U.C. Irvine L. Rev. Available at https://ssrn.com/abstract $=3053980$

Geiger C, Izyumenko E (2019) Freedom of expression as an external limitation to copyright law in the EU: the Advocate General of the CJEU shows the way. Eur Intellect Prop Rev

Gelke (2013) Mashups im Urheberrecht. Nomos Verlagsgesellschaft mbH \& Co. KG, Baden-Baden

Geller PE (2010) A German approach to fair use: test cases for TRIPs criteria for copyright limitations? J Copyr Soc U.S.A. 57:901

Goldstein P, Hugenholtz B (2010) International copyright: principles, law, practice. OUP, Oxford

Griffiths J, McDonagh L (2013) Fundamental rights and European IP law: the case of Art. 17(2) of the EU charter. In: Geiger C (ed) Constructing European intellectual property: achievements and new perspectives. Edward Elgar Publishing, Cheltenham

Häuser M (2002) Sound und sampling. Beck Juristicher Verlag, München

Holm-Hudson K (1997) Quotation and context: sampling and John Oswald's plunderphonics. Leonardo Music J 7:17-25 
Hugenholtz PB, Senftleben M (2011) Fair use in Europe: in search of flexibilities. Amsterdam. Available at https://papers.ssrn.com/sol3/papers.cfm?abstract_id=1959554

Katz M (2010) Capturing sound: how technology has changed music. University California Press, Berkeley

Lacasse S (2000) Intertextuality and hypertextuality in recorded popular music. In: Talbot M (ed) The musical work: reality or invention? Liverpool University Press, Liverpool

Leistner M (2014) Urheberrecht in der digitalen Welt. JuristenZeitung (JZ) 69(17):846-857. https://doi. org/10.1628/002268814X14060241209325

Leistner M (2016) Die "Metall auf Metall"-Entscheidung des BVerfG oder: Warum das Urheberrecht in Karlsruhe in guten Händen ist. GRUR 772-777

McLeod K, Di Cola P (2011) Creative license: the law and culture of digital sampling. Duke University Press, Durham

Morrison DM (2008) Bridgeport redux: digital sampling and audience recoding. Fordham Intellect Prop Media Entertain Law J 19:75

Ohly A (2017) Hip Hop und die Zukunft der "freien Benutzung" im EU-Urheberrecht Anmerkungen zum Vorlagebeschluss des BGH "Metall auf Metall III". GRUR 964-969

Okpaluba J (2000) Digitisation, culture and copyright: digital sampling, a case study. Ph.D. King's College, University of London

Peers S et al (2014) The EU Charter of Fundamental Rights: a commentary. Hart Publishing, Oxford

Peukert A (2015) The fundamental right to (intellectual) property and the discretion of the legislature. In: Geiger C (ed) Research handbook on human rights and intellectual property. Edward Elgar Publishing, Cheltenham

Podszun R (2016) Postmoderne Kreativität im Konflikt mit dem Urheberrechtsgesetz und die Annäherung an 'fair use'. Z für Urh- und Medienrecht 60:606

Ricketson S, Ginsburg JC (2006) The Berne Convention and beyond. OUP, Oxford

Salagean (2008) Sampling im deutschen, schweizerischen und US-amerikanischen Urheberrecht. Nomos Verlagsgesellschaft mbH \& Co. KG, Baden-Baden

Sanjek D (1992) 'Don't have to DJ no more' Sampling and the 'autonomous creator'. Cardozo Arts Entertain Law J 10:607

Senftleben MRF (2012) Quotations, parody and fair use. In: Bernt Hugenholtz P, Quaedvlieg AA, Visser DJG (eds) A century of Dutch copyright law - Auteurswet 1912-2012. deLex, Amstelveen

Szymanski RM (1996) Audio pastiche: digital sampling, intermediate copying, fair use. UCLA Entertain Lae Rev 3(2):273

V. Ungern-Sternberg J (2014) Die Rechtsprechung des EuGH und des BGH zum Urheberrecht und zu den verwandten Schutzrechten im Jahre 2013. GRUR 209-224

Xalabarder R (2009) Study on copyright limitations and exceptions for educational activities in North America, Europe, Caucasus, Central Asia and Israel. WIPO, Geneva

Publisher's Note Springer Nature remains neutral with regard to jurisdictional claims in published maps and institutional affiliations. 